iletișim / Contact Mail : info@humanisticperspective.com Web : https://dergipark.org.tr/tr/pub/hp

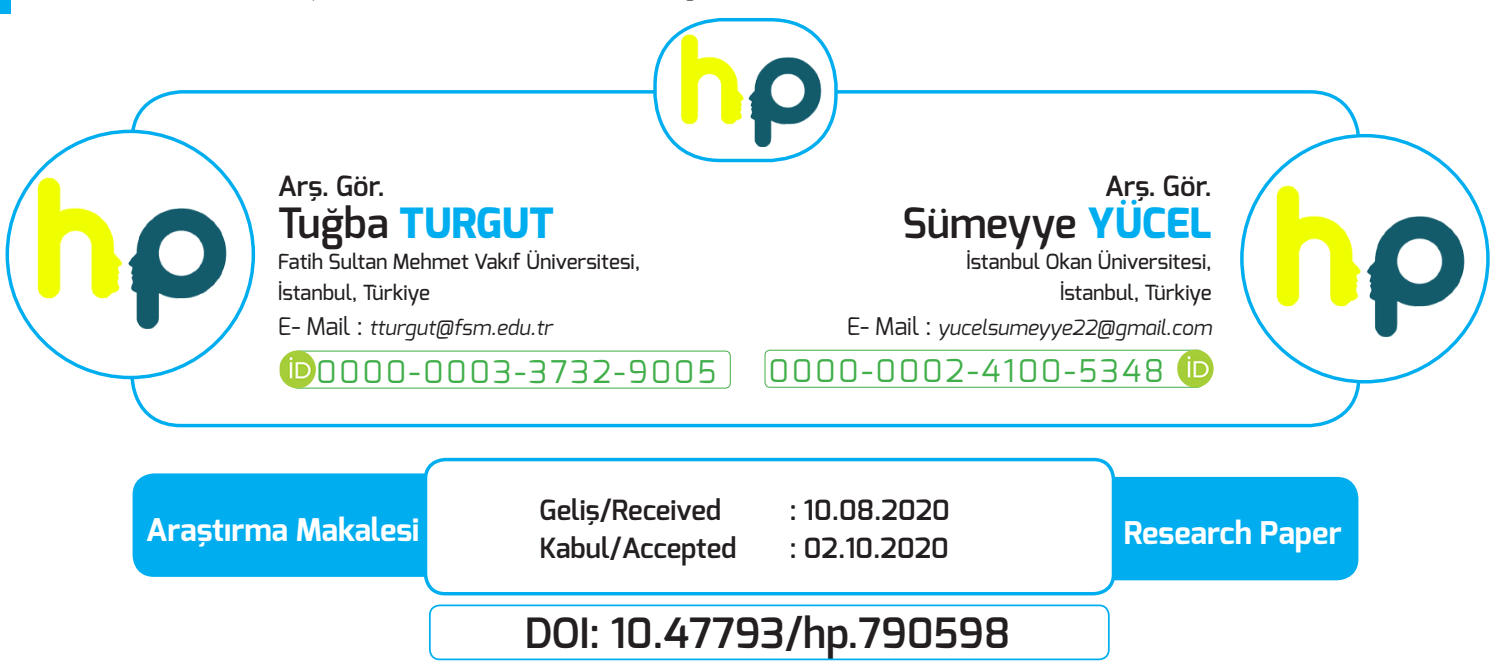

\title{
Beliren ve Genç Yetişkinlerde Koşulsuz Kendini Kabul ve İlişki Bağımlılığı Arasındaki İlişkide Olumsuz Değerlendirilme Korkusunun Aracı Rolünün İncelenmesi*
}

\section{ÖZET}

Bu çalışmanın amacı; beliren ve genç yetişkinlerde koşulsuz kendini kabul ile ilişki bağımlılığı arasındaki ilişkide olumsuz değerlendirilme korkusunun aracı rolünün incelenmesidir. Ayrıca koşulsuz kendini kabul, ilişki bağımlılı̆̆1 ve olumsuz değerlendirilme korkusunun birtakım demografik değişkenler bakımından ele alınması da amaçlanmıştır. Araştırmanın çalışma grubunu, $256(\% 80,5)$ kadın ve $62(\% 19,5)$ erkek olmak üzere toplam 318 birey oluşturmaktadır. Araştırmada Demografik Bilgi Formu, Spann-Fischer İlişki Bağımlllı̆̆ Ölçeği, Koşulsuz Kendini Kabul Ölçeği ve Olumsuz Değerlendirilme Korkusu Ölçeği veri toplama araçları olarak kullanılmıştır. Araştırmanın amaçlarını test etmek için verilerin analizinde Bağımsız Grup t testi, ANOVA (Tek Yönlü Varyans Analizi), Pearson Momentler Çarpımı Korelasyonu, Koşullu Süreç Analizi ve Bootstrapping analizi kullanılmıştır. Gerçekleştirilen analizler neticesinde; beliren ve genç yetişkinlerde ilişki bağımlılı̆̆ı, koşulsuz kendini kabul ve olumsuz değerlendirilme korkusu arasında anlamlı ilişkiler bulunmaktadır. Kurulan modelde koşulsuz kendini kabul ile ilişki bağımlılığı arasındaki ilişkide olumsuz değerlendirilme korkusunun kısmi aracı rolü olduğu sonucuna ulaşılmıştır. Ayrıca demografik değişkenler olan medeni durum, ebeveyn tutumları ve gelişim dönemlerine göre anlamlı farklılıkların olduğu sonucuna ulaşılmaktadır.

Anahtar Kelimeler: ilişki bağımlihğ, koşulsuz kendini kabul, olumsuz değerlendirilme korkusu, beliren ve genc yetişkinler, koşullu süreç analiz̨i

\section{The Investigation of the Mediating Role of Fear of Negative Evaluation in the Relationship Between Unconditional Self-Acceptance and Codependency in Emerging and Young Adults}

\begin{abstract}
The aim of this study is to examine the mediating role of fear of negative evaluation in the relationship between unconditional self-acceptance and codependency in emerging and young adults. It also aims to examine unconditional self-acceptance, codependency and fear of negative evaluation in terms of various demographic variables. The sample of the study consists of a total of 318 people, $256(80.5 \%)$ female and $62(19.5 \%)$ male. The Demographic Information Form, Spann-Fischer Codependency Scale, Unconditional Self-Acceptance Scale and Fear of Negative Evaluation Scale were used in the data gathering process. In order to test the aims of the research, Independent Group t test, ANOVA (One-Way Analysis of Variance), Pearson ProductMomentCorrelation, ConditionalProcess Analysis and Bootstrapping analysis were used in the analysis of the data. The results of this study indicate that, there are significant relationships between codependency, unconditional self-acceptance and fear of negative evaluation in emerging and young adults. In the model established, it was concluded that fear of negative evaluation had a partial mediating role in the relationship between unconditional self-acceptance and codependency. In addition, it is concluded that there are significant differences according to the demographic variables such as marital status, parental attitudes and developmental periods.
\end{abstract} Keywords: codependency, unconditional self-acceptance, fear of negative evaluation, emerging and young adults, conditional process analysis 


\section{GİRİ̧̧}

B irey dünyaya gelmeye hazırlandığı dönemden itibaren ilişki kurmak da onunla birlikte yol alır (Condon ve Corkindale, 1997; Cranley, 1981). Doğum öncesinde başlayan bu ilişki süreci doğumun ardından yaşamın farklı dönemlerinde, bireyin gelişim alanlarında yansımalarını gösterir (Alhusen, Hayat ve Gross, 2013; Siddiqui ve Hagglöf, 2000). İlişki kurmanın bu denli derin ve temel bir gereksinim olduğu kaçınılmazken bireyin sahip olduğu özellikler, ilişkide bulunduğu ötekilerin nitelikleri ve ilişkilere yüklenen anlam da yaşanan ve yaşanacak olan ilişkilerin biçimini ve kalitesini etkileyebilmektedir (Bartholomew, 1990; Bowlby, 1969; Kapçı ve Küçüker, 2006). Bu ilişki biçimlerinden biri de bağımlılığa varan ilişkilerin kurulmasıdır.

İlişki bağımlılı̆̆ı kavramı ilk olarak alkol ya da madde bağımlısı bireyi olan ailelerde ortaya çıkmış, eşlerden birinin bağımlı olması ve diğerinin de onu toplumsal açıdan korumaya çalışarak farkında olmadan eşinin bağımlılığına katkıda bulunması durumuna "ilişki bağımlılığı" denilmiştir (Cretser ve Lombardo, 1999). 1989 yllında Amerika'da düzenlenen “Uluslararası İlişki Bağıml1lığ1 Konferansı"nda ise ilişki bağımlılı̆̆1 bireyin yüksek bir öz-sayg1ya sahip olmak için ötekilerin düşüncelerini kabul edip benimsemesi olarak ifade edilmiştir (Tolstikova, 2010). İlişki bağımlılı̆̆1 konusunda araştırmalar yapılmaya devam ettikçe ebeveyni alkol bağımlısı olan bireyler, duygusal veya ruhsal açıdan sorunları olan bireylerle ilişkide olanlar, yardım grubu çalışanları gibi farklı örneklemlerde ilişki bağımlılığı durumu ile karşılaşılmıştır (Beattie, 1992). Yapılan çalışmaların ilişki bağımlılığı konusunda daha çok bireylerin ihlal ya da ihmali, travmatize olma gibi durumlarla ilişkili olduğu ortaya konmuştur (Akhunlar, 2010; Chang, 2010; Loughead, 1991).

Bu çerçevede ilişki bağımlılı̆̆ı; ötekini kaybedeceğine ya da kızdıracağına dair endişe, düşük Öz-sayg1 ve sosyal kaygının eşlik ettiği, kurulmuş olan ilişkiyi öteki açısından da kontrol altına alarak sürdürme anlamına gelebilir (Cengiz, 2018). Kişilerarası ilişkilerde ötekine aşırı müdahalede bulunmak, kendi duygularını ifade etmekten kaçınmak ilişki bağımlılı̆ının tanımında ifade edilen özelliklerdir (Fischer, Spann ve Crawford, 1991).

Tanımda belirtilen ötekini kaybetme korkusu, oluşan kaygılar ve düşük öz-sayg1 gibi durumlar ilişki bağımlılı̆̆ında bireyin diğerleri tarafindan olumsuz değerlendirileceği korkusunu da beraberinde getirebileceği düşünülmektedir. Olumsuz değerlendirilme korkusu; sosyal kaygının belirtilerinden biri olarak karşımıza çıkmaktadır (Uğur, 2018). Kavram, ötekilerin fikirlerini aşırı derecede önemseme, değerlendirileceğini ve bunun olumsuz yargılarla sonuçlanacağını düşünerek ortamlardan ve olumsuz duygu halinden kaçınma olarak ifade edilebilir (Bilge ve Kelecioğlu, 2008; Irmak, 2015). Bireyin kendiliğine yönelik algıları, olumlu veya olumsuz inançları, önceki deneyimleri, onaylanma ihtiyacı gibi etkenler ilişkide olduğu bireylerin kendisiyle ilgili neler düşüneceğine dair yargisı olumsuz değerlendirme korkusuna zemin hazırlamaktadır (Rapee ve Heimberg, 1997; Schlenker ve Leary, 1982). Sapmaz’in (2011) ifade ettiği haliyle; söz konusu korkunun engellenmesine yönelik bireylerin (a) kaçınma; olumsuz değerlendirilme korkusu yaşayan bireyin korkuyu ortaya çıkaran durum veya koşullardan uzaklaşması; (b) kaçma; bireyin zorunlu olarak bulunması gerekli olan sosyal ortamlarda kalmak istemeyerek bir an önce ayrılmak için uğraşması ve son olarak (c) güvenlik sağlayıcı davranışlar; bireyin, olumsuz değerlendirme korkusunu bastırmak veya düzeyini indirgemek 
Ekim 2020, Cilt 2, Sayı 3

October 2020, Volume 2, Issue 3
İletișim / Contact

Mail : info@humanisticperspective.com Web : https://dergipark.org.tr/tr/pub/hp

amacıyla uyguladığı davranışsal baş etme stratejilerine başvurduğu bir süreç olan olumsuz değerlendirilme korkusu; daha çok düşük öz-saygı ile ilişkili bulunarak bireyin kendisine yönelik olumsuz inançları, hedeflerine ulaşamayacağı düşüncesi ile karakterize edilmiştir (Leary ve Kowalski, 1995). Bu noktada kendilik tasarımı, kendiliğe ilişkin alg1, kendiliğe verilen değer ve kendini kabul gibi kavramlar konuyla ilgili olarak incelenmeye değer görülmektedir.

$\mathrm{Bu}$ araştırmanın bileşenlerinden bir diğerini oluşturan koşulsuz kendini kabul; Ellis’e (1973) göre "Bireyin herhangi bir özelliği ya da eylemi açısından onaylanma ihtiyacı hissetmeden kendini kabul etmesi” olarak tanımlanmıştır (akt. Kapıkıran ve Kapıkıran, 2010). Diğerlerinin görüşleri, değerlendirmeleri bireyin kendisiyle ilgili algilarına etki edebilir ancak bu durumun kendisini ne saf iyi ne de saf kötü olarak değerlendirmesine yol açmaması gerektiğine inanılmaktadır (Yılmaz-Bingöl ve Vural-Batık, 2018). Kendine gerçekçi bir gözle bakmak ve değerlendirmekle yakından ilişkili olan koşulsuz kendini kabul durumunu sağlayan birey; (1) kendiliğini kabul eder ve öz-saygısı yüksektir; (2) çıkarlarına uygun davranmadı̆̆ında da kendini kabul eder ve öz-saygisında eksilme olmaz (3) kendiliği yerine düşünce, duygu ve eylemlerini değerlendirir (Ellis, 2005). Kendisini başkalarına ispat etmek yerine kendine olan saygısını ve sevgisini arttırmaya çalışan, kendisini koşulsuz kabul eden bireyler bu sayede başkalarının onayını alma konusunda 1srarcı veya bu konuda ihtiyaç sahibi olmazlar (Ellis ve Bernard, 1985; Ellis ve Harper, 1997).

Tüm bu çerçevede özetlenecek olursa; başlangıçta madde bağımlılı̆̆ıla ilgili bir kavram olarak ele alınan ilişki bağımlılı̆̆ının son yıllarda sosyal ve yakın kişilerarası ilişkiler bağlamında ele alındığ1 görülmektedir. Beliren yetişkinlik ve genç yetişkinlik dönemleri de bireylerin yaşamlarında farklı alanlarda performanslar sergiledikleri, kimlik kazanımının olmasının beklendiği ve kişilerarası ilişkileri başlatma ve sürdürme faaliyetlerinin yoğunlukta olduğu bir dönem olarak karşımıza çıkmaktadır. Beliren ve genç yetişkinlik dönemlerindeki bireylere yönelik hazırlanan bu çalışmada; alan yazın incelendiğinde ilişki bağımlılı̆̆ı hakkında gerçekleştirilen araştırmaların sayısının yurtiçinde sınırlı sayıda olduğu söylenebilir (Cengiz, 2019; Havaçeliği, 2013; Mukba, 2013). Bu anlamda ilişki bağımlılığını ayrıntılı inceleme düşüncesi ve aynı zamanda ilişki bağımlılı̆̆ı, koşulsuz kendini kabul, olumsuz değerlendirilme korkusunun bir arada incelendiği herhangi bir araştırmaya rastlanmamış olması bu çalışmanın temel çıkış noktasını oluşturmaktadır. Koşulsuz kendini kabul ile ilişki bağımlılı̆̆1 arasındaki ilişkide olumsuz değerlendirilme korkusunun arac1 rol üstlenebileceği düşünülerek yeni bir model üzerinden yapılandırılması önemli görülmüştür. Bu nedenle bu araştırmanın amac1; beliren ve genç yetişkinlerde koşulsuz kendini kabul ile ilişki bağımlılı̆̆1 arasındaki ilişkide olumsuz değerlendirilme korkusunun aracı rolünün incelenmesidir. Ayrıca ilişki bağımlılığı, koşulsuz kendini kabul ve olumsuz değerlendirilme korkusunun; cinsiyet, medeni durum, gelişim dönemi ve ebeveyn tutumu gibi çeşitli demografik değişkenler bakımından da ele alınması amaçlanmaktadır.

\section{YÖNTEM}

\section{Araştırma Modeli}

Bu araştırma, koşulsuz kendini kabul ve ilişki bağımlılığı arasındaki ilişkide olumsuz değerlendirilme korkusunun aracı rolünü incelemeye ilişkin ilişkisel tarama modelinde yapılandırılmıştır. İlişkisel tarama modelleri; iki ve daha fazla sayıdaki değişkenlerin birlikte değişimini, aralarında bulunan 
ilişkiyi ve bu ilişkilerin derecesini belirlemeyi amaçlayan modellerdir (Karasar, 2018). Bu çalışmada değişkenlerin arasındaki ilişkilerin bağımlı, bağımsız ve aracı değişken içeren bir yapısal eşitlik modeli üzerinden incelenmesi amaçlanmıştır. Yapısal eşitlik modeli; gözlenen veya örtük değişkenler arasındaki ilişkileri, doğrudan ve dolaylı etkileri içeren modelleri test etmek amacıyla kullanılan çok değişkenli istatistiksel analizleri içeren bir yaklaşımdır (Hoyle, 1995; Kline, 2018). Model kurgulanırken koşulsuz kendini kabul bağımsız değişken, olumsuz değerlendirilme korkusu aracı değişken ve ilişki bağımlılı̆̆ı da bağımlı değişken olarak tanımlanmıştır.

\section{Evren ve Örneklem}

Araştırmanın evrenini beliren ve genç yetişkinlik dönemindeki bireyler, çalışma grubunu ise uygun (kolay ulaşılabilir) örnekleme yöntemi aracıllğıyla belirlenen, beliren ve genç yetişkinlik dönemlerinde (18-45 yaş) bulunan toplam 318 birey oluşturmaktadır. Örneklemi oluşturan bireylerin 256’s1 (\%80.5) kadın ve 62'si (\%19.5) erkektir. Uygun örnekleme, katılımcıların çalışmaya uygunluğunu ve araştırmaya yönelik istekliliğini ön planda tutarak yakın ve kolay ulaşılabilen bireylerle gerçekleştirilen örneklem türüdür (Creswell, 2017). Örneklem grubunu oluşturan bireylerin yaş ortalaması 24.68 olarak hesaplanmıştır.

\section{Veri Toplama Araçları}

Demografik Bilgi Formu: Demografik bilgi formunda; araştırmaya katılan örneklemin yaş1, cinsiyeti, medeni durumu, öğrenim durumu, aile bilgileri, anne baba tutumları, algıladıkları sosyal destek gibi demografik özelliklerine ilişkin sorular bulunmaktadır.

Spann-Fischer İlişki Bağımlılı̆̆1 Ölçeği: Fischer, Spann ve Crawford’un (1991) geliştirdiği ve Tanhan ve Mukba'nın (2014) Türk kültürüne uyarlama çalışmasını yaptığ1 ölçektir. Ölçek 6’lı likert tipli ve 16 sorudan oluşmakta ve bireylerin ilişkilerdeki bağımlılık seviyesini ölçmeyi amaçlamaktadır. Ölçek tek faktörlü bir yapıda olduğu için yap1 geçerliğine bakılmamış, ölçüt bağıntılı geçerlik için Rosenberg Benlik Sayg1sı Ölçeği (RBSÖ) ve Genel Sağl1k Anketi'yle (GSA-12) kullanılarak anlamlı ilişkiler olduğu saptanmıştır. Ölçeğe ait Cronbach Alpha güvenirlik katsayısı .65 olarak saptanmıştır. Mevcut araştırma için Cronbach Alpha katsayısı .79 olarak hesaplanmıștır.

Koşulsuz Kendini Kabul Ölçeği: Chamberlain ve Haaga (2001) tarafindan geliştirilen ve Türk kültürüne uyarlama çalışması Kapıkıran ve Kapıkıran (2010) tarafindan gerçekleştirilen bir ölçektir. Ölçek temelde Ellis'in Akılcı Duygusal Davranış Terapisi'ne dayanmaktadır. Koşullu kendini kabul ve koşulsuz kendini kabul olmak üzere iki alt boyuttan meydana gelmektedir. Ölçek toplam varyansın \%36.77'sini açıklarken, ayırt edici geçerliği için uygulanan Sosyotropi ve Kısa Semptom Envanteri ve Fonksiyonel Olmayan Tutumlar Ölçeği puanlarıyla anlamlı düzeyde ilişki olduğu sonucuna ulaşılmıştır. Ölçeğin yapı geçerliğine ilişkin uyum indekslerinin $(\chi 2 / \mathrm{sd}=2.45, \mathrm{RMSEA}=.08$, SRMR=.09) kabul edilebilir düzeyde olduğu görülmektedir. Ölçek "benim için doğru" ile "benim için doğru değil" arasında değişen 7'li likert tipinde ve toplam 19 maddeden meydana gelmektedir. Ölçeğin güvenirliğini test etmek üzere gerçekleştirilen analizlerde Cronbach Alpha katsayısı .76 ve 
İletișim / Contact

Mail : info@humanisticperspective.com Web : https://dergipark.org.tr/tr/pub/hp

test tekrar test korelasyonu r=.62 olarak hesaplanmıştır. Bu çalışma kapsamında hesaplanan Cronbach Alpha güvenirlik katsayısının .79 olduğu belirlenmiştir.

Olumsuz Değerlendirilme Korkusu Ölçeği-Kısa Formu: Leary (1983) tarafindan geliştirilen ve Türk kültürüne adaptasyonu Çetin, Doğan ve Sapmaz (2010) tarafindan gerçekleştirilen bir ölçektir. Bir insanın başka bireyler tarafından olumsuz değerlendirilmeye karşı davranışlarını, toleransını ölçmeye ilişkin geliştirilmiştir. Psikometrik özellikleri açısından test-tekrar test, iç tutarlılık, testi yarılama yöntemleri, açımlayıcı ve doğrulayıcı faktör analizleri ile ölçüt bağıntılı geçerlik için Sosyal Görünüş Kaygısı Ölçeği kullanılmıştır. Açımlayıcı ve doğrulayıcı faktör analizleri sonucuna göre ölçeğin tek faktörlü bir yapıya sahip olduğu sonucuna ulaşılmıştır. Ölçeğin yapı geçerliğine ait uyum değerlerinin (RMSEA =.062, NFI=.96, CFI=.98, $\mathrm{IFI}=.98, \mathrm{RFI}=.95$ ve $\mathrm{AGFI}=.92)$ kabul edilebilir aralıklarda yer aldığı görülmektedir. "Hiç uygun değil” "uygun değil” "biraz uygun" "uygun” “tamamen uygun” şeklinde 5’li likert tipindedir ve 11 maddeden oluşan ölçekte Cronbach Alpha iç tutarlık katsayısı değeri .84 ve test-tekrar-test güvenirlik katsayısı .82 şeklinde hesaplanmıştır.

\section{İşlem}

Araştırmaya ait uygulamalara yönelik araştırmacılar tarafindan hazırlanan Demografik Bilgi Formu, Spann-Fischer İlişki Bağımlılı̆̆ı Ölçeği, Koşulsuz Kendini Kabul Ölçeği ve Olumsuz Değerlendirilme Korkusu Ölçeği-Kısa Formu tek bir form haline getirilerek çevrimiçi platformlar aracılı̆̆ıyla katılımcılara ulaştırılmıştır.

\section{Verilerin Analizi}

Araştırma kapsamında toplanan veriler SPSS 23.0 programı ve Process Makro eklentisi aracılığıyla analiz edilmiştir. Araştırma amaçlarını incelemek için; Bağımsız Gruplar t testi, ANOVA, Pearson Momentler Çarpımı Korelasyonu, Koşullu Süreç Analizi ve Bootstrapping analizi gerçekleştirilmiştir.

\section{BULGULAR}

Tablo 1: İlişki Bağımlılığı Ölçeği, Olumsuz Değerlendirilme Korkusu Ölçeği ve Koşulsuz Kendini Kabul Ölçeğine İlişkin Betimsel İstatistik Değerleri

\begin{tabular}{lccccc}
\hline Değişkenler $(\mathrm{N}=318)$ & $\overline{\mathrm{x}}$ & ss & $\mathrm{Sh}_{\overline{\mathrm{x}}}$ & Min. & Max. \\
\hline İlişki Bağımlılı̆̆1 & 55.5063 & 12.22 & .68579 & 22.00 & 89.00 \\
Olumsuz Değerlendirilme Korkusu & 31.4308 & 5.88 & .33012 & 18.00 & 46.00 \\
Koşulsuz Kendini Kabul & 78.5377 & 14.51 & .81424 & 39.00 & 118.00 \\
\hline
\end{tabular}

Tablo 1'de görüldüğü üzere ilişki bağımlılı̆̆1, olumsuz değerlendirilme korkusu ve koşulsuz kendini kabul değişkenlerine ilişkin betimsel istatistik sonuçları yer almaktadır. İlişki bağımlılığ1 puan ortalaması (55.50) standart sapma değeri (12.22), olumsuz değerlendirilme korkusu puan ortalaması (31.43) standart sapma değeri (5.88) ve koşulsuz kendini kabul puan ortalaması (78.53) standart sapma değeri (14.51) olarak hesaplanmıştır. Bu sonuçlar beliren ve genç yetişkinlerde ilişki 
bağımlılı̆̆ı, olumsuz değerlendirilme korkusu ve koşulsuz kendini kabul düzeylerinin ortalamanın üzerinde olduğunu göstermektedir.

Tablo 2. Cinsiyete, Medeni Duruma, Gelişim Dönemine İlişkin Yapılan Bağımsız Gruplar t Testi Sonuçları

\begin{tabular}{|c|c|c|c|c|c|c|c|c|c|}
\hline & \multicolumn{3}{|c|}{ Cinsiyet } & \multicolumn{3}{|c|}{ Medeni Durum } & \multicolumn{3}{|c|}{ Gelişim Dönemi } \\
\hline & \multicolumn{3}{|c|}{ 1. Kadin } & \multicolumn{3}{|c|}{ 1. Bekar } & \multicolumn{3}{|c|}{ 1.Beliren Yetişkin } \\
\hline & \multicolumn{3}{|c|}{ 2. Erkek } & \multicolumn{3}{|c|}{ 2. Evli } & \multicolumn{3}{|c|}{ 2.Genç Yetişkin } \\
\hline Puanlar & $\mathrm{t}$ & $\mathrm{p}$ & A. Fark & $\mathrm{t}$ & $\mathrm{p}$ & A. Fark & $\mathrm{t}$ & $\mathrm{p}$ & A. Fark \\
\hline $\begin{array}{l}\text { İlişki Bağımlilığı } \\
\text { Olumsuz }\end{array}$ & 1.60 & .109 & --- & 1.24 & .213 & --- & .096 & .924 & --- \\
\hline Değerlendirilme & 1.26 & .206 & --- & 3.31 & $.001 *$ & $1>2$ & 2.67 & $.008 *$ & $1>2$ \\
\hline Korkusu & & & & & & & & & \\
\hline Koşulsuz Kendini Kabul & -.718 & .474 & --- & -1.83 & .068 & --- & -1.82 & .069 & --- \\
\hline
\end{tabular}

Cinsiyete ilişkin yapılan Bağımsız Gruplar t Testi sonucunda; ilişki bağımlılı̆̆ı, olumsuz değerlendirilme korkusu ve koşulsuz kendini kabul değişkenlerinin tümünde erkekler ve kadınlar arasında anlamlı bir farklılaşma olmadığı görülmektedir ( $p>$.05). Medeni durum değişkeni açısından gruplar arasında anlamlı bir farklılaşma olup olmadığını incelemek amacıyla gerçekleştirilen Bağımsız Gruplar t Testi sonucunda; bekar bireylerin evli bireylere göre olumsuz değerlendirilme korkular1nın daha yüksek olduğu görülmektedir $(t=3.31 ; p<.01)$. Gelişim dönemine ilişkin gerçekleştirilen Bağımsız Gruplar t Testi sonucunda; beliren yetişkinlik döneminde yer alan bireylerin genç yetişkinlik döneminde yer alan bireylere göre olumsuz değerlendirilme korkularının daha fazla olduğu görülmektedir $(t=2.67 ; p<.05)$.

Tablo 3. Anne-Baba Tutumlarına İlişkin İlişki Bağımlılı̆̆ı, Olumsuz Değerlendirilme Korkusu ve Koşulsuz Kendini Kabul Değişkenlerinin Farklılaşıp Farklılaşmadığına Yönelik Gerçekleştirilen One-Way ANOVA Analizi Sonuçları

\begin{tabular}{|c|c|c|c|}
\hline \multicolumn{4}{|c|}{ Anne-Baba Tutumları } \\
\hline & \multicolumn{3}{|c|}{$\begin{array}{l}\text { 1. Aşır1 Koruyucu } \\
\text { 2.Baskıc1/Otoriter } \\
\text { 3. İzin Verici } \\
\text { 4. Demokratik }\end{array}$} \\
\hline Puanlar & $\mathrm{F}$ & $\mathrm{p}$ & Anlamli Fark \\
\hline İlişki Bağımlılı̆̆1 & 6.22 & $.000^{*}$ & $1>4,2>4,3>4$ \\
\hline Olumsuz Değerlendirilme Korkusu & 2.38 & .069 & --- \\
\hline Koşulsuz Kendini Kabul & 2.48 & .060 & --- \\
\hline
\end{tabular}

Anne baba tutumlarına göre anlamlı farklılık için yapılan ANOVA sonucunda; aşırı koruyucu, baskıc1/otoriter ve izin verici anne baba tutumlarına sahip olan bireylerin demokratik anne baba tutumuna sahip olan bireylere göre ilişki bağımlılığı düzeyleri yüksek olduğu saptanmıştır $(F=6.22$; 
$p<.001)$.

Tablo 4. İlişki Bağımlılı̆̆1 Ölçeği, Olumsuz Değerlendirilme Korkusu Ölçeği ve Koşulsuz Kendini Kabul Ölçeği Arasındaki İlişkiler

\begin{tabular}{|c|c|c|c|}
\hline \multirow{2}{*}{$\begin{array}{l}\text { Değişkenler } \\
\text { 1.İlişki Bağımlılığ1 }\end{array}$} & 1. & 2. & 3. \\
\hline & & & \\
\hline 2.Olumsuz Değerlendirilme Korkusu & $.57 *$ & & \\
\hline 3.Koşulsuz Kendini Kabul & $-.47 *$ & $-.64 *$ & \\
\hline
\end{tabular}

İlişki bağımlılı̆̆ı, olumsuz değerlendirilme korkusu ve koşulsuz kendini kabul arasındaki ilişkileri incelemek için gerçekleştirilen Pearson Korelasyon Analizi sonucunda; ilişki bağımlılığı, olumsuz değerlendirilme korkusu ve koşulsuz kendini kabul değişkenleri arasında orta düzeyde anlamlı ilişkiler bulunmaktadır. Beliren ve genç yetişkinlerde ilişki bağımlılığı yüksek olan bireylerin olumsuz değerlendirilme korkularının yüksek, koşulsuz kendini kabul düzeylerinin düşük olduğu sonucu karşımıza çıkmaktadır. Ayrıca koşulsuz kendini kabul düzeyi düşük olan bireylerin olumsuz değerlendirilme korkularının daha yüksek olduğu görülmektedir.

Koşulsuz Kendini Kabul ve İlişki Bağımlılığı Arasındaki İlişkide Olumsuz Değerlendirilme Korkusunun Aracı Rolüne İlişkin Bulgular

Koşulsuz kendini kabul ve ilişki bağımlılı̆̆ı arasındaki ilişkide olumsuz değerlendirilme korkusunun aracı rolünü incelemeye yönelik ilk olarak; bağımsız değişken (koşulsuz kendini kabul) ile bağımlı değişken (ilişki bağımlılığı) arasındaki ilişkileri, bağımsı değişkenin bağımlı değişkeni yordama düzeyini incelemek amacıyla istatistiksel analizler yapılmış ve Şekil 1'de gerçekleştirilen yordama modeli sunulmuştur.

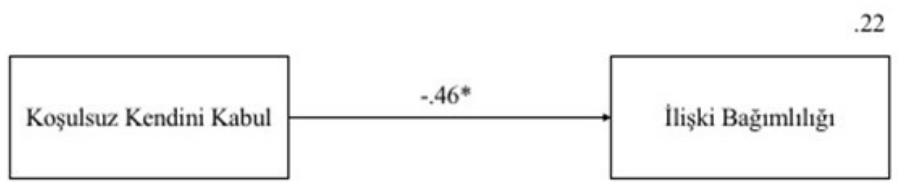

Şekil 1. Koşulsuz Kendini Kabul ve İlişki Bağımlılı̆̆ Arasındaki İlişkiyi Yordama Modeli

Şekil 1 incelendiğinde koşulsuz kabul değişkeni ile ilişki bağımlılı̆̆1 değişkeni arasında $(r=-.46$; $p<.001)$ negatif yönlü anlamlı bir ilişki olduğu görülmektedir. Koşulsuz kendini kabul değişkeninin ilişki bağımlılı̆̆ı değişkenine orta seviyede doğrudan anlamlı bir etkisi bulunmaktadır (\%95 GA [-.4768 -.3121]). Koşulsuz kendini kabulün ilişki bağımlılığını \%22 oranında açıkladığı görülmektedir $\left(R^{2}=.22 ; p<.001\right)$. Baron ve Kenny'e (1986) göre aracilik analizinin uygulanabilmesi için; a) bağımsız değişkende meydana gelen değişiklikler arac1 değişken üzerinde etkili olmalı, b) arac1 değişkende oluşan değişiklikler bağımlı değişken üzerinde değişikliğe sebep olmalı ve c) aracı ve 
bağımsız değişken aynı anda analize sokulduğunda bağımsı değişkenin bağımlı değişken üzerindeki etkisi düşmeli ya da tamamen ortadan kalkmalı şeklinde belirtilen varsayımların sağlanması gerekmektedir. Şekil 1'de elde edilen bu sonuç bağımlı, bağımsız, aracı değişken içeren aracı model çalışmasını yapmanın ön şartlarından birisi olan; yordayan (koşulsuz kendini kabul) ve yordanan (ilişki bağımlılı̆̆ı) arasındaki ilişki anlamlı olmalıdır koşulunu desteklemektedir (Civelek, 2018). Bu analiz sonrasında çalışmanın temel amacı olan koşulsuz kendini kabul ve ilişki bağımlılığı arasındaki ilişkide olumsuz değerlendirilme korkusunun aracı rolünü incelemeye yönelik gerçekleştirilen koşullu süreç analizine geçilmiştir.

Koşullu süreç analizi; bir değişkenin başka bir değişken üzerindeki etkisini ilettiği yolların veya mekanizmaların (aracı veya düzenleyici değişkenler) koşullu doğasını belirlemek ve değişkenler arasındaki çoklu ilişkileri ele almak için gerçekleştirilen regresyon temelli bir yaklaşımdır (Hayes, 2018). Aracılık analizi bir değişkenin bir veya daha fazla aracı değişken aracılı̆̆ıyla başka bir değişken üzerindeki doğrudan ve dolaylı etkileri incelemek amacıyla gerçekleştirilmektedir (Hayes, 2018; Preacher, Rucker ve Hayes, 2007). Koşulsuz kendini kabul ve ilişki bağımlılığı arasındaki ilişkide olumsuz değerlendirilme korkusunun aracı rolünü incelemek amacıyla koşullu süreç analizi gerçekleştirilmiştir. Koşullu süreç modelinde koşulsuz kendini kabul bağımsız değişken, olumsuz değerlendirilme korkusu aracı değişken ve ilişki bağımlılı̆̆ı da bağımlı değişken olarak tanımlanmıştır. Modele ilişkin bulgular Şekil 2'de sunulmuştur.

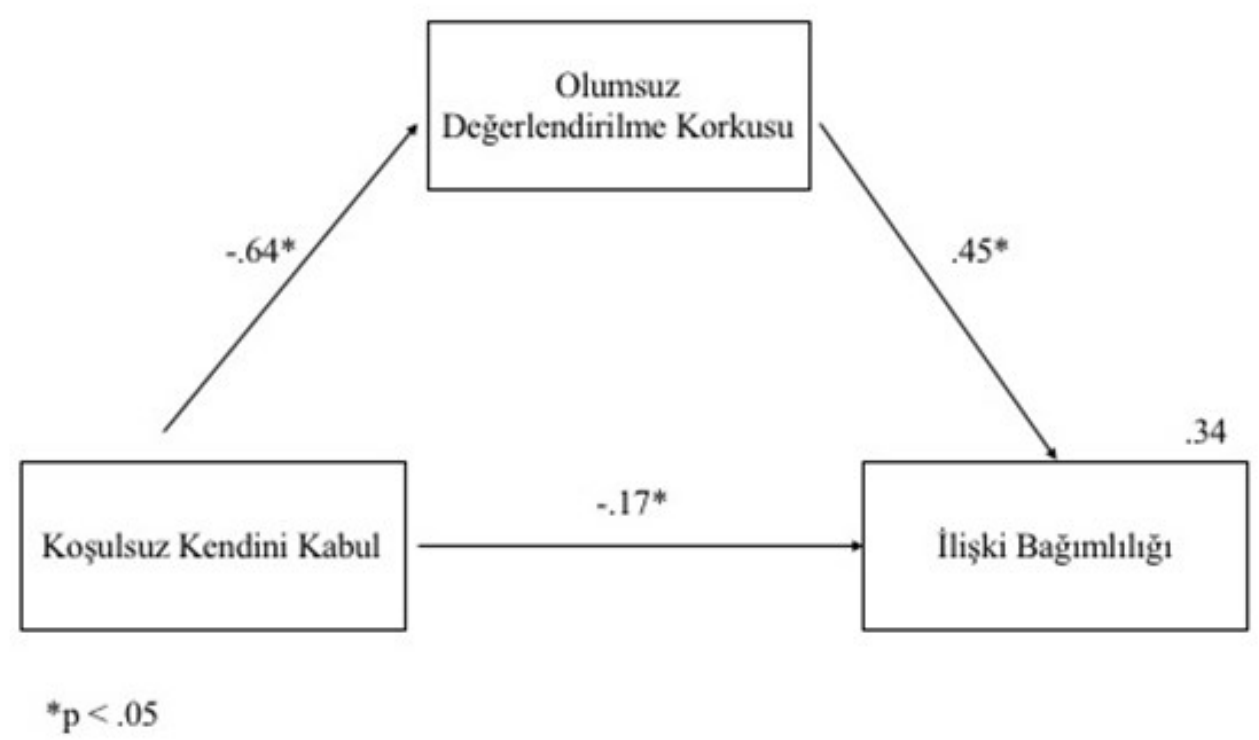

Şekil 2. Koşulsuz Kendini Kabul ve İlişki Bağımlılığı Arasındaki İlişkide Olumsuz Değerlendirilme Korkusunun Aracı Rolünün İncelenmesine Yönelik Oluşturulan Model

Çalışmanın asıl amacı olan koşulsuz kendini kabul değişkeninin ilişki bağımlılı̆̆ı ile olan ilişkisinde olumsuz değerlendirilme korkusunun aracı rolünün incelenmesine ilişkin sonuçlar Şekil 2'de verilmiştir. Model incelendiğinde ilk modelde (şekil 1) yer alan koşulsuz kendini kabul ile ilişki 
İletișim / Contact

Mail : info@humanisticperspective.com Web : https://dergipark.org.tr/tr/pub/hp

bağımlılı̆̆1 arasında $(r=-.46 ; p<.001)$ olan ilişkinin olumsuz değerlendirilme korkusu değişkeni ile beraber $(r=-.17 ; p<.05)$ seviyesine düştüğü ve ilişkinin anlamlılı̆̆ını koruduğu görülmektedir. Modelden elde edilen bu sonucun aracı rol etkisinin incelendiği çalışmalarda; aracı değişken modele dahil edildiğinde bağımsız değişken ile bağımlı değişken arasındaki ilişkiyi aracı değişken ya anlamlı seviyede düşürmeli ya da anlamlılık tamamen ortadan kalkmalıdır ön koşulunu sağladığ1 görülmektedir (Baron ve Kenny, 1986). Buradan çıkan sonuca göre, koşulsuz kendini kabul ile ilişki bağımlılı̆̆ı arasında olan anlamlı ilişki modele olumsuz değerlendirilme korkusunun dahil edilmesiyle düşmekte ancak anlamlılı̆̆ını korumaktadır. Başka bir ifadeyle koşulsuz kendini kabul değişkeni ve ilişki bağımlılı̆̆ı değişkeni arasındaki ilişkide olumsuz değerlendirilme korkusunun kısmi aracı rolü olduğu sonucuna ulaşılmıştır. Modelde ilişki bağımlılığı değişkeninin toplam varyansının \%34’lük bir kısmı açıklanmaktadır $\left(R^{2}=.34 ; p<.001\right)$.

Kurulan modelde olumsuz değerlendirilme korkusunun aracı rolünün anlamlı olup olmadığını incelemek amacıyla Bootstrapping analizi gerçekleştirilmiş ve Tablo 5’te verilmiştir.

Tablo 5. Doğrudan ve Dolaylı Etkilere İlişkin Bootstrapping Analizi Sonuçları

\begin{tabular}{llll}
\hline Test Edilen Yol & \multirow{2}{*}{$\mathrm{Sh}_{\mathrm{x}} \frac{\% 95 \text { Güven Aralı̆̆1 }}{\text { Alt Sınır Üst Sınır }}$} \\
\hline
\end{tabular}

\section{Doğrudan}

Koşulsuz Kabul $\longrightarrow$ Olumsuz Değ. Korkusu

$$
-.64 * \quad .017 \quad-.2948 \quad-.2261
$$

Olumsuz Değ. $\longrightarrow$ İlişki Bağımlılı̆̆

$.45^{*} \quad .124 \quad .7006 \quad 1.1886$

Koşulsuz Kabul $\longrightarrow$ İlişki Bağımlılı̆̆1

$-.46^{*} \quad .041 \quad-.4768 \quad-.3121$

\section{Dolayl1}

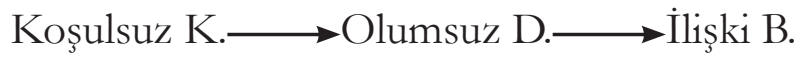
$-.29 * \quad .040 \quad-.3745$ $-.2149$ ${ }^{*} p<, 001$

Tablo 5’te görüldüğü üzere olumsuz değerlendirilme korkusu değişkeninin modeldeki arac1 rolünün anlamlı olup olmadığına ilişkin gerçekleştirilen Bootstrapping analizi sonuçları yer almaktadır. Bootstrapping analizi, geleneksel yöntemlerle elde edilen sonuçlardan daha doğru bir olasılık/ tahmin ortaya koymak amaciyla orijinal bir örneklemden tekrar örneklem seçme temeline dayanan ve kurulan modeldeki yol katsayılarının ve aracılık etkisinin anlamlılı̆̆ını inceleyen bir yaklaşımdır (Lockwood ve MacKinnon, 1998). Aracılığın anlamlı olup olmadığını belirlemek amacıyla bootstrap değeri (yeniden örneklem sayısı) 10000 olarak belirlenmiştir. Doğrudan ve dolaylı etki katsayıları \%95 güven aralığı esas alınarak incelenmiştir. Koşulsuz kendini kabul ve ilişki bağımlılığı arasındaki ilişkide olumsuz değerlendirilme korkusunun kısmi arac1 rolünün anlamlı olup olmadığ1 \%95 güven aralığında incelendiğinde alt ve üst sınırlar arasında sıfır değerinin olmadığı tespit edilmiştir. Alt ve üst değerler arasında sıfırın yer almaması aracılık rolünün anlamlı bir şekilde kabul edildiğini ifade etmektedir. Elde edilen bu sonuç olumsuz değerlendirilme korkusu değişkeninin modelde anlamlı 
bir şekilde kısmi aracı bir role sahip olduğunu göstermektedir (\%95 GA [-.3745 -.2149]).

\section{SONUÇ, TARTIŞMA VE ÖNERİLER}

Araştırma kapsamında gerçekleştirilen analizler neticesinde ilk olarak fark analizleri sonuçları incelendiğinde, bazı demografik değişkenlere göre anlamlı farklılıkların olduğu görülmektedir. Araştırma bulguları bağlamında ilişki bağımlılığı, olumsuz değerlendirilme korkusu ve koşulsuz kendini kabul değişkenlerinin cinsiyete göre anlamlı bir farklılaşma göstermediği, bu özellikler açısından çalışmada yer alan erkek ve kadın bireylerin farklılaşmadığı sonucuna ulaşılmıştır. Alan yazında kadınların kişilerarası bağımlılık düzeylerinin erkeklere göre yüksek olduğuna yönelik bu çalışmada elde edilen bulgulardan farklı sonuçlara rastlanmaktadır (Bornstein, Manning, Krukonik, Rossner ve Mastrosimone 1993; Pincus ve Wilson, 2001) Koşulsuz kendini kabul düzeylerinin cinsiyete göre farklılık göstermediğine ilişkin Yılmaz-Bingöl ve Vural-Batık (2018), David, Cotet, Szentagotai, McMahon ve DiGiuseppe (2013) tarafindan gerçekleştirilen çalışmalarda benzer bulgulara rastlanmaktadır. Bu çalışmada elde edilenden farklı olarak kadınların erkeklere göre kendini kabul etme eğilimlerinin yüksek olduğuna (Cenkseven, 2004; Kuyumcu ve Rohner, 2018) dair bulgular da literatürde yer almaktadır. Olumsuz değerlendirilme korkusunun cinsiyete göre anlamlı farklılık göstermediğine ilişkin Erkan, Güçray ve Çam (2002), Koydemir ve Demir (2007), Irmak (2015), Çam, Sevimli ve Yerlikaya (2010), Cenk (2019) gibi çeşitli çalışmalar yer almakta ve bu çalışmada elde edilen sonucu desteklemektedir. Medeni duruma göre incelendiğinde bekar bireylerin evli bireylere göre daha yüksek seviyede olumsuz değerlendirilme korkularının olduğu; gelişim dönemine göre bakıldığında beliren yetişkinlik döneminde yer alanların genç yetişkinlik döneminde yer alanlara göre olumsuz değerlendirilme korkularının yüksek olduğu sonucuna ulaşılmıştır. Beliren yetişkinlik dönemindeki bireylerin bir kimlik inşası sürecinde oldukları göz önünde bulundurulduğunda romantik ilişki, meslek yaşamı ve dünya görüşü açısından keşif sürecini yaşadıkları söylenebilir (Arnett, 2000). İçinde bulunulan dönemin yaşanılan toplumdan ve kültürden bağımsız değerlendirilemeyeceği kabul edilirse beliren yetişkinlerin bulundukları gelişim özellikleri açısından özellikle toplulukçu kültürlerde daha kısa bir dönem olarak yaşanabildiği söylenebilir (Donoghue ve Stein, 2007). Bu duruma ülkemizde evlilik ve işe başlama yaşının özellikle kırsal bölgelerde daha düşük olması; dezavantajı bölgelerde yaşayan bireylerin beliren yetişkinlik dönemindeki eğitim alma, kendini geliştirme, sosyalleşme gibi faaliyetlerinden uzak kalmasına sebep olarak gösterilebilir. Bir evin sorumluluğunu alma(ma), ebeveyninin bakımını üstlenme(me), toplumun evliliğe bakış açısı gibi durumlarla karşı karşıya kalan beliren yetişkinlerin diğerlerince olumsuz değerlendirilebileceklerine ilişkin inançlarının olması olasıdır. Literatürde yer alan Cenk (2019) tarafindan gerçekleştirilen çalışmada bekar bireylerin evli bireylere göre olumsuz değerlendirilme korkularının yüksek olduğuna yönelik benzer bulgulara rastlanırken, gelişim dönemine göre incelenen Cenk (2019) çalışmasında yaşa göre olumsuz değerlendirilme korkusu düzeyinde farklılaşma olmadı̆̆1 yani beliren ve genç yetişkinlere göre farklılaşmadığına ilişkin farklı bulgulara rastlanmaktadır. Anne-baba tutumlarına göre; aşırı koruyucu, baskıcı/otoriter ve izin verici anne baba tutumlarına sahip olan bireylerin demokratik anne baba tutumuna sahip olan bireylere göre ilişki bağımlılığı düzeylerinin yüksek olduğu saptanmıştır. Otoriter ebeveyn stilinin demokratik ebeveyn stiline göre kadın ve erkeklerde ilişki bağımlılığına daha yüksek seviyede etki ettiği ifade edilmektedir (Fisher ve Crawford, 1992). Fonk- 
Ekim 2020, Cilt 2, Sayı 3

October 2020, Volume 2, Issue 3
İletișim / Contact

Mail : info@humanisticperspective.com

Web : https://dergipark.org.tr/tr/pub/hp

siyonel olmayan aile, ebeveyn stilleri ve kişilerarası ilişkilerin ilişki bağımlılı̆̆ının devam etmesinde etkili olduğu çeşitli çalışmalarda belirtilmektedir (Crothers ve Warren, 1996; Schaef, 1986). Otoriter ebeveyn stiline sahip bireylerin daha fazla ilişki bağımlılı̆̆1 gösterdiğine (Carfora, 2009) ve kronik aile stresiyle ilişki bağımlılı̆̆ının anlamlı ilişkiye sahip olduğuna (Fuller ve Warner, 2000) dair benzer bulgular yer almaktadır.

Çalışmanın asıl amacını yansıtan modele yönelik bulgular incelendiğinde, koşulsuz kendini kabul ile ilişki bağımlılı̆̆ı arasındaki ilişkide olumsuz değerlendirilme korkusunun aracı rolüne ilişkin yapılan analizler sonucunda modelin kabul edilir düzeyde uyumlu olduğu tespit edilmiştir. Koşulsuz kendini kabulün ilişki bağımlılığına orta düzeyde doğrudan bir etkisinin olduğu, modele olumsuz değerlendirilme korkusunun dahil edilmesiyle bu ilişkinin seviyesinin düştüğü ancak anlamlılı̆̆ını koruduğu, koşulsuz kendini kabulün olumsuz değerlendirilme korkusu üzerinden ilişki bağımlılı̆̆1na dolaylı etkisinin olduğu görülmektedir. Bu sonuçlar koşulsuz kendini kabul ile ilişki bağımlılı̆̆1 ilişkisinde olumsuz değerlendirilme korkusunun kısmi arac1 rolünün olduğuna işaret etmektedir. Modele göre koşulsuz kendini kabul seviyeleri düşük olan bireylerin başkaları tarafindan olumsuz değerlendirilmeye yönelik korkularının yüksek olacağ1 ve koşulsuz kendini kabulleri ile olumsuz değerlendirilme korkuları fazla olan bireylerin ilişki bağımlılı̆̆1 seviyelerinin yüksek olacağ1 anlaşılmaktadır. Literatürde birebir aynı değişkenlere ilişkin çalışma yer almamakla birlikte bu bulguları destekler nitelikte bazı çalışmalara rastlanmaktadır. Durm ve Glaze (2001) tarafından yapılan araştırmada kendini kabulü düşük olan bireylerin olumsuz değerlendirilme korkularının yüksek olduğu bulunmuştur. Alford-Keating (1991) çalışmasında kendini kabul seviyesi düşük olan gay ve lezbiyen bireylerin olumsuz değerlendirilme korkularının yüksek olduğu görülmektedir. Kapıkıran ve Kapikıran (2010) tarafından gerçekleştirilen çalışmada koşulsuz kendini kabulü düşük olanların onaylanma kaygısı, başkalarını memnun etme durumu, onaylanma ihtiyacının yüksek olduğuna ilişkin sonuçlar, bu çalışmada ulaşılan koşulsuz kendini kabulü düşük olan bireylerin başkaları tarafindan olumsuz değerlendirilmeye ilişkin korkularının yüksek olduğu sonucuyla benzer niteliktedir. Beth (1999) çalışmasında negatif benlik ifadelerine sahip kadın ve erkeklerin olumsuz değerlendirilme korkularının yüksek olduğu sonucu elde edilmiştir. Ümmet, İme, Çağlar ve Aky1l (2020) tarafindan yapılan araştırmada karar verme sürecinde özsaygısı düşük olan lise öğrencilerinin olumsuz değerlendirilme korkularının yüksek olduğu belirtilmektedir. Çelik ve Atilla (2019), Cankardaş (2019) tarafından gerçekleştirilen çalışmalarda benzer şekilde benlik saygısı düşük olan bireylerin olumsuz değerlendirilme korkularının fazla olduğu ifade edilmektedir. Cheng, Zhang ve Ding (2015) araştırmasında düşük aile sosyoekonomik düzeyi düşük benlik saygisına sebep olmakta ve bu da yüksek olumsuz değerlendirilme korkusuna ve sosyal kaygiya sebep olmaktadır. Ercanlar (2019) tarafindan yapılan araştırmada kendine ilişkin öz yeterlik inancı düşük olan bireylerin başkaları tarafından olumsuz değerlendirilmeye yönelik korku düzeylerinin yüksek olduğu saptanmıştır. Literatürde yer alan bu çalışmalar ile, mevcut çalışmada ulaşılan koşulsuz kendini kabulü düşük olan beliren ve genç yetişkinlerin yüksek olumsuz değerlendirilme korkusu duyacağ1 sonucuyla örtüşür niteliktedir.

Modelde yer alan olumsuz değerlendirilme korkusu fazla olan beliren ve genç yetişkinlerin daha yüksek seviyede ilişki bağımlılı̆̆ı göstereceği sonucuna ilişkin literatürde benzer nitelikte birtakım çalışmalar yer almaktadır. Ben (2017) tarafindan gerçekleştirilen çalışmada olumsuz değerlendirilme 
korkusu olan bireylerin sosyal anksiyete, kayg1, sosyal görünüş kayg1sı yaşadığ1 ifade edilmekte, bu çalışmada yer alan olumsuz değerlendirilme korkusu yüksek olan bireylerin ilişki bağımlılığını daha yüksek seviyede göstermesi ve ilişki bağımlılığıyla birlikte sosyal kayg1 yaşama ihtimallerinin fazla olmasıyla benzer niteliktedir. Kanbur (2018) tarafından gerçekleştirilen çalışmada olumsuz değerlendirilme korkusu fazla olan çalışanların örgütsel sessizlik seviyelerinin fazla olduğu yani çalışılan kurumda sessiz kalma, davranışta bulunmama ve yapılan şeyleri kabullenme durumlarının yüksek olduğu görülmekte ve bu sonuç olumsuz değerlendirilme korkusu yüksek olan bireylerin ilişki bağımlılı̆̆ının fazla olması yani ilişkide diğerlerinin davranışlarını kabullenme, kendinden ödün verme, duygularını dışarı yansıtmada eksiklik gibi davranışların yaygın olması ile benzer niteliktedir. Wells, Hill, Brack, Brack ve Firestone (2006) tarafından yapılan araştırmada yakınlık ve ilişkide incinme korkusu duyan bireylerin ilişki bağımlılı̆̆1 gösterme eğilimlerinin yüksek olacağı ifade edilmektedir.

Modelde ayrıca koşulsuz kendini kabulü düşük olan beliren ve genç yetişkinlerin ilişki bağımlılığ1 gösterme eğiliminin daha yüksek olacağı sonucu karşımıza çıkmaktadır. Literatürde ilişki bağımlılı̆̆1 ile benlik saygısı arasında negatif yönlü anlamlı ilişkilerin olduğuna yönelik Springer, Britt ve Schlenker (1998), Marks, Blore, Hine ve Dear (2012) Fischer vd. (1991) ve Cook ve Barber (1997) çeşitli çalışmalar yer almaktadır. Bu sonuç koşulsuz kendini kabulü düşük olan bireylerin ilişki bağımlılığ1 seviyesinin yüksek olduğuna ilişkin bulguya benzer niteliktedir. Cucu-Ciuhan ve Dumitru (2017) tarafindan gerçekleştirilen çalışmada koşulsuz kendini kabulün, benlik saygısının düşük olması, fonksiyonel olmayan olumsuz duygular ve depresyon gibi patolojik durumlarla ilişkili bulunmuştur. Godin (2010) çalışmasında koşulsuz kendini kabulü yüksek bireylerin psikolojik iyi oluşlarının da yüksek olduğu görülmektedir. Kapıkıran ve Kapıkıran (2010) araştırmasında koşulsuz kendini kabulü düşük olan bireylerin daha fazla anksiyete, depresyon, olumsuz benlik, somatizasyon ve düşmanlık gibi psikolojik semptomları daha fazla gösterdiğini bulgulamıştır. Koşullu kendini kabul ile onaylanma kaygısı ve başkalarını memnun etme arasında da pozitif, ayrılık kaygısı ile negatif yönde anlamlı ilişkilerin bulunduğu araştırmalara rastlanmıştır (Davies 2008; Flett, Besser, Davis, ve Hewitt, 2003; Sohlberg, Axelsson, Czartoryski, Ståhlberg ve Strömbom, 2006). Bu sonuçlar çalışmada elde edilen koşulsuz kendini kabulün düşük olduğu bireylerde ilişki bağımlılı̆̆1nın yüksek olduğu bulgularıyla tutarlılık göstermektedir. Chang (2010) tarafından yapılan çalışmada benlik saygısı düşük olan ve bağımlı benlik yapısı sergileyen Amerikalı ve Tayvanlı bireylerin ilişki bağımlılıklarının daha fazla olduğu sonucuna ulaşılmıştır. Lindley, Giordano ve Hammer (1999) çalışmasında düşük özgüvene sahip bireylerin daha yüksek seviyede ilişki bağımlılı̆̆ı sergilediği ifade edilmektedir. Tüm bu sonuçlar koşulsuz kendini kabulün düşük olmasının patolojik durumlarla, yüksek olmasının psikolojik sağlıkla ilişkili olduğunu ve düşük kendini kabulün daha fazla ilişki bağımlılı̆̆1 eğilimiyle ilişkili olduğunu açıklar mahiyettedir.

Sonuç olarak beliren ve genç yetişkinlerin kendilerini koşulsuz olarak kabul ettiklerinde başkaları tarafından olumsuz değerlendirilmeye ilişkin korkularının ve içinde bulundukları ilişkilerde ilişki bağımlılığ1 gösterme eğilimlerinin düşük düzeyde olacağ1 görülmektedir. Bu anlamda araştırmada oluşturulan modelin alanda eksik kalan noktalara yönelik farklı bakış açıları getireceği ve alana faydalı olacağı düşünülmektedir.

Araştırmada elde edilen sonuçlar neticesinde birtakım öneriler sunulabilir. Odak grup veya 
iletișim / Contact Mail : info@humanisticperspective.com Web : https://dergipark.org.tr/tr/pub/hp

nitel görüşmelerin derinlemesine çalışmalar yapılmasına imkan sağlayacağı düşünülmektedir. Farklı örneklemler üzerinde çalışmalar gerçekleştirilebilir. Bireylerin koşulsuz kendini kabul düzeylerini artırmaya yönelik psikoeğitim programları, farkındalık temelli grup çalışmaları gerçekleştirilebilir. Günümüzde okul öncesi eğitim kurumlarından üniversitelere kadar her bir eğitim kademesinde bulunan ruh sağlığı uzmanı olan psikolojik danışman/psikologların sahadaki uygulamalarında; çocukluktan itibaren bireylere sağlıklı ilişkiler kurmalarını destekleyecek şekilde kendilerini koşulsuz kabul etmeleri için profesyonel yardım sunmalarının toplum ruh sağlığı açısından da oldukça faydalı olacağı düşünülmektedir. Bireylerin ilişki bağımlılıklarının ve olumsuz değerlendirilme korkularının azaltılabileceği müdahalelerin yer aldığı deneysel araştırmalar yapılırken koşulsuz kendini kabulün dikkate alınması önerilebilir. Bireylerin farklı aktivitelere yönlendirilmesi ile ilişki bağımlılıklarından uzaklaşması sağlanabilir. İlişki bağımlılı̆̆ı, koşulsuz kendini kabul ve olumsuz değerlendirilme korkusu ile ilgili olabilecek başka değişkenlerin ekleneceği farklı araştırmalar tasarlanabilir.

\section{KAYNAKÇA}

Akhunlar, M. N. (2010). Üniversite ögrencilerinin bağlanma stilleri ile uyum süreģleri arasındaki ilişkinin incelenmesi (Yayımlanmamış yüksek lisans tezi). Maltepe Üniversitesi Sosyal Bilimler Enstitüsü, İstanbul.

Alford-Keating, P. M. (1991). Degree of openness about a gay/lesbian orientation as related to fear of negative evaluation, self-acceptance, and internalized homophobia (Unpublished Doctoral dissertation), Oklahoma State University.

Alhusen, J. L., Hayat, M. J. \& Gross, D. (2013). A longitudinal study of maternal attachment and infant developmental outcomes. Archieves of Women's Mental Health, 16(6), 521-529.

Arnett, J. J. (2000) Emerging adulthood: A theory of development from the late teens through the twenties. American Psychologist, 55(5), 469-480. https://doi.org/10.1037/0003-066X.55.5.469

Baron, R. M. \& Kenny, D. A. (1986). The moderator-mediator variable distinction in social psychological research: Conceptual, strategic, and statistical considerations. Journal of Personality and Social Psychology, 51(6), 1173-1182.

Bartholomew, K., (1990). Avoidance of intimacy: An attachment perspective. Journal of Social and Personal Relationships, 7(2), 147-178.

Beattie, M. (1992). Codependet no more: How to stop controlling others and start caring for yourself. Hazelden Publishing.

Ben, S. (2017). Istanbul'da yaşayan üniversite ögrencilerinin sosyal anksiyete düzeyleri ile beden algısı olumsuz. 
değerlendirilme korkusu sosyal görünüş kaygısı arasındaki ilişkinin incelenmesi (Yayımlanmamış yüksek lisans tezi). Haliç Üniversitesi Sosyal Bilimler Enstitüsü, İstanbul.

Beth, P. (1999). Childhood and adolescent abuse history, fear of negative evaluation, and social interaction self-statements: A correlational analysis. Child and Adolescent Social Work Journal, 16(1), 47-65.

Bilge, F. ve Kelecioğlu, H. (2008). Olumsuz Değerlendirilme Korkusu Ölçeği-Türkçe formunun psikometrik özellikleri. Eurasian Journal of Educational Research, 32, 21-38.

Bornstein, R. F., Manning, K. A., Krukonis, A. B., Rossner, S. C. \& Mastrosimone, C. C. (1993). Sex differences in dependency: A comparison of objective and projective measures. Journal of Personality Assessment, 61(1),169-181.

Bowlby, J. (1969). Attachment and loss: Vol. 1. Attachment, New York: Basic Books.

Cankardaş, S. (2019). Kadın ve erkeklerde olumsuz değerlendirilme korkusunun belirlenmesinde algilanan ebeveyn tutumları ve benlik saygisının rolü. Psikoloji Calısmalar/ Studies in Psychology, 39(1), 79-97.

Carfora, R. E. (2009). Codependency among only children as predicted by parenting styles practiced in family-oforigin (Unpublished master's thesis). Smith College Scholl of Social Work, Northampton.

Cengiz, N. (2018). Üniversite ögrrencilerinde iliskki bağımlilı̆gnm bağlanma stilleri açısından incelenmesi (Yayımlanmamış yüksek lisans tezi). İstanbul Okan Üniversitesi Sosyal Bilimler Enstitüsü, İstanbul.

Cenk, D. K. (2019). Genc yetişkinlerde yeme tutumu ile olumsuz değerlendirilme korkusu arasindaki iliskinin incelenmesi (Yayımlanmamış yüksek lisans tezi). Üsküdar Üniversitesi Sosyal Bilimler Enstitüsü, İstanbul.

Cenkseven, F. (2004). Üniversite ögrrencilerinde öænel ve psikolojik iyi olmann yordayucularmm incelenmesi (Yayımlanmamıs doktora tezi). Çukurova Üniversitesi Sosyal Bilimler Enstitüsü, Adana.

Chamberlain, J. M. \& Haaga, D. A. (2001). Unconditional self-acceptance and psychological health. Journal of Rational-Emotive and Cognitive-Behavior Therapy, 19(3), 163-176.

Chang, S. H. (2010). Codependency among college students in the United States and Taiwan: A cross-cultural study (Unpublished doctoral dissertation). Ohio University, USA. 
Cheng, G., Zhang, D. \& Ding, F. (2015). Self-esteem and fear of negative evaluation as mediators between family socioeconomic status and social anxiety in Chinese emerging adults. International Journal of Social Psychiatry, 61(6), 569-576.

Civelek, M. E. (2018). Yapısal esittik modellemesi metodolojisi. İstanbul: Beta Yayınc1lık.

Condon, J. T. \& Corkindale, C. J. (1997). The assesment of parent-to-infant attachment: Development of a Self-Report Questionnaire Instrument. Journal of Reproductive and Infant Psychology, 16(1), $57-76$.

Cook, D. L. \& Barber, K. R. (1997). Relationship between social support, self-esteem and codependency in the African American female. Journal of Cultural Diversity, 4(1), 32-38.

Cranley, M. S. (1981). Development of a tool for the measurement of maternal attachment during pregnancy. Nursing Research, 30(5), 281-284.

Creswell, J. W. (2017). Eğitim arastırmalarn nicel ve nitel araștırmanm planlanması, yürütülmesi ve değerlendirilmesi. (H. Ekşi, Çev. Ed.). İstanbul: EDAM Yayınları.

Cretser, G. A. \& Lombardo, W. K. (1999). Examining codependency in a college population. College Student Journal, 33(4), 629-637.

Crothers, M. \& Warren, L. W. (1996). Parental antecedents of adult codependency. Journal of Clinical Psychology, 52(2), 231-239.

Cucu-Ciuhan, G. \& Dumitru, I. E. (2017). Unconditional self-acceptance, functional and dysfunctional negative emotions, and self-esteem as predictors for depression in adolescents: A brief pilot study conducted in Romania. Journal of Experiential Psychotherapy/Revista de PSIHOterapie Experientiala, 20(4).

Çam, S., Sevimli, D. ve Yerlikaya, E. (2010). Olumsuz Değerlendirilmekten Korkma Ölçeği’ne (ODKÖ) ilişkin bir geçerlik ve güvenirlik çalışması. Ç.Ü. Sosyal Bilimler Enstitüsü Dergisi, 19(1), 132-140.

Çelik, Y. ve Atilla, G. (2019). Üniversite öğrencilerinde kendini sabotaj, olumsuz değerlendirilme korkusu ve benlik sayg1sı. Kahramanmaraş Sütçü Imam Üniversitesi İktisadi ve İdari Bilimler Fakültesi Dergisi, 9(2), 177-198.

Çetin, B., Doğan, T. ve Sapmaz, F. (2010). Olumsuz Değerlendirilme Korkusu Ölçeği Kısa Formu’nun Türkçe uyarlamas1: Geçerlik ve güvenirlik çalışması. Eğitim ve Bilim, 35(156), 205-216. 
David, D., Cotet, C. D., Szentagotai, A., McMahon, J. \& Digiuseppe, R. (2013). Philosophical versus psychological unconditional acceptance: Implications for constructing the unconditional acceptance questionnaire. Journal of Cognitive and Behavioral Psychotherapies, 13 (2), 445-464.

Davies, M. F. (2008). Irrational beliefs and unconditional self-acceptance. III. The relative importance of different types of irrational belief. Journal of Rational-Emotive \& CognitiveBehavior Therapy, 26(2), 102-118.

Donoghue, C. \& Stein P. J. (2007) Diversity in adult experiences and criteria for adulthood among university students. College Student Journal, 41 (4), 831-842.

Durm, M. W. \& Glaze, P. E. (2001). Construct validity for self-acceptance and fear of negative evaluation. Psychological Reports, 89(2), 386-386.

Ellis, A. (2005). The myth of self-esteem: How rational emotive behavior therapy can change your life forever. Amherst, New York, USA: Prometheus Books.

Ellis, A. \& Bernard, M. E. (1985). What is rational-emotive therapy (RET)? In A. Ellis and M.E. Bernard (Eds.), Clinical applications of rational emotive therapy (pp. 1-30). Ne York, USA: Plenum.

Ellis, A. \& Harper, R. A. (1997). A guide to rational living (3rd Ed.). North Hollywood, CA: Wilshire.

Ercanlar, M. (2019). Fransızca yabancı dil öğrencilerinin olumsuz değerlendirilme korkusu ve Özyeterlilik inançları. Anadolu Üniversitesi Eğitim Fakültesi Dergisi (AUJEF), 3(4), 239-252.

Erkan, Z., Güçray, S. ve Çam, S. (2002). Ergenlerin sosyal kaygı düzeylerinin ana baba tutumları ve cinsiyet açısından incelenmesi. Cukurova Üniversitesi Sosyal Bilimler Enstitüsü Dergisi, 10, 64-75.

Fischer, J. L. \& Crawford, D. W. (1992). Codependency and parenting styles. Journal of Adolescent Research, 7(3), 352-363.

Fischer, J. L., Spann, L. \& Crawford, D. (1991). Measuring codependency. Alcoholism Treatment Quarterly, 8, 87-100.

Flett, G. L., Besser, A., Davis, R. A. \& Hewitt, P. L. (2003). Dimensions of perfectionism, unconditional self-acceptance, and depression. Journal of Rational-Emotive and CognitiveBehavior Therapy, 21(2), 119-138.

Fuller, J. A. \& Warner, R. M. (2000). Family stressors as predictors of codependency. Genetic Social and General Psychology Monographs, 126(1), 5-24. 
Godin, J. (2010). The effect of the Enneagram on psychological well-being and unconditional self-acceptance of young adults (Unpublished doctoral dissertation). Iowa State University, Ames Iowa.

Havaçeliği, D. (2013). Partner ilişkilerindeki ilişki bağımliluğmm ebeveyn bağlanma stilleri ve madde kullanım ile ilişkisi (Yayımlanmamış yüksek lisans tezi). Ege Üniversitesi Sağlık Bilimleri Enstitüsü, İzmir.

Hayes, A. F. (2018). Introduction to mediation, moderation, and conditional process analysis a regression-based approach. New York: The Guilford Press.

Hoyle, R. H. (1995). Structural equation modeling concepts, issues and applications. United States of America: SAGE Publications.

Irmak, M. (2015). Ortä̈ğretim ögrrencilerinin olumsuz değerlendirilme korkusu ve ögrenmeye ilişkin tutumlarmm incelenmesi (Yayımlanmamış yüksek lisans tezi). Erciyes Üniversitesi Eğitim Bilimleri Enstitüsü, Kayseri.

Kanbur, E. (2018). Çalışanların olumsuz değerlendirilme korkusunun örgütsel sessizlik üzerine etkisi. İsletme Arastormalarn Dergisi, 10(1), 382-402.

Kapç1, E. G. ve Küçüker, S. (2006). Ana Babaya Bağlanma Ölçeği: Türk üniversite öğrencilerinde psikometrik özelliklerinin değerlendirilmesi. Türk Psikiyatri Dergisi, 17(4), 286-295.

Kapıkıran, N. A. ve Kapıkıran, Ş. (2010). Koşulsuz Kendini Kabul Ölçeği’nin Türk üniversite öğrencileri için geçerliği ve güvenirliği. Kriz Dergisi, 18(1), 33-44.

Karasar, N. (2018). Bilimsel arastırma yöntemi kavramlar ilkeler teknikler. Ankara: Nobel Yayınc1lik.

Kline, R. B. (2019). Yapısal esittik modellemesinin ilkeleri ve uygulaması. (S. Şen, Çev.). Ankara: Nobel Yayincilik.

Koydemir, S. \& Demir, A. (2007). Psychometric properties of the Brief Fear of Negative Evaluation Scale in a Turkish sample. Psychological Reports, 100, 883-893.

Kuyumcu, B. \& Rohner, R. P. (2018). The relation between remembered parental acceptance in childhood and self-acceptance among young Turkish adults. International Journal of Psychology, 53, 2, 126-132. https://doi.org/10.1002/ijop.12277

Leary, M. R. (1983). A brief version of the Fear of Negative Evaluation Scale. Personality and Social Psychology Bulletin, 9, 371-376. 
Leary, M. R. \& Kowalski, R. M. (1995). The self-presentation model of social phobia. In Heimberg, R. G., Liebowitz, M. R., Hope, D. A. Schneider, F. R, eds. Social Phobia: Diagnosis, Assessment and Treatment. New York: Guilford Press (pp. 94-112).

Lindley, N. R., Giordano, P. J. \& Hammer, E. D. (1999). Codependency: Predictors and psychometric issues. Journal of Clinical Psychology, 55(1), 59-64.

Lockwood, C. M. \& MacKinnon, D. P. (1998, March). Bootstrapping the standard error of the mediated effect. In Proceedings of the 23rd annual meeting of SAS Users Group International (pp. 997-1002).

Loughead, T. A. (1991). Addictions as a process: Commonalties or codependence. Contemporary Family Threapy, 13, 455-470.

Marks, D., G., Blore, R., L., Hine, W., D. \& Dear, E., G. (2012). Development and validation of a revisedmeasure of codependency. Australian Journal of Psychology, 64, 119-127.

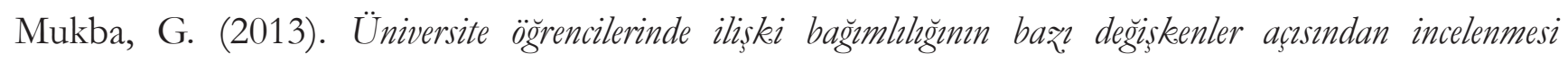
(Yayımlanmamış yüksek lisans tezi). Yüzüncü Yıl Üniversitesi Eğitim Bilimleri Enstitüsü, Van.

Pincus, A. L. \& Wilson, K. R. (2001). Interpersonal variability in dependent personality. Journal of Personality, 69 (2), 224-251.

Preacher, K. J., Rucker, D. D. \& Hayes, A. F. (2007). Addressing moderated mediation hypotheses: Theory, methods, and prescriptions. Multivariate Behavioral Research, 42(1), 185-227.

Rapee, R. M. \& Heimberg, R.G. (1997). A cognitive-behavioral model of anxiety in social phobia. Behaviour Research and Therapy, 35 (8), 741-756.

Sapmaz, F. (2011). Bilişsel davranış̧ yaklaşıma dayal grupla psikolojik danısmanm sosyal anksiyete, reddedilme duyarlhlğ̆ ve kişilerarası duyarlılı üz̧erine etkisi (Yayımlanmamış doktora tezi). Sakarya Üniversitesi Eğitim Bilimleri Enstitüsü, Sakarya.

Schaef, A. W. (1986). Co-dependence: Misunderstood-mistreated. San Francisco: Harper \& Row.

Schlenker, B. R. \& Leary, M. R. (1982). Social anxiety and self-presentation: A conceptualization model. Psychological Bulletin, 92(3), 641-669. https://doi.org/10.1037/0033-2909.92.3.641

Siddiqui, A. \& Hägglöf, B. (2000). Does maternal prenatal attachment predict postnatal mother- 
infant interaction? Early Human Development, 59(1), 13-25. https:/ / doi.org/10.1016/S03783782(00)00076-1

Sohlberg, S., Axelsson, J., Czartoryski, W., Ståhlberg, G. \& Strömbom, Y. (2006). Sociotropy, autonomy, and depressive response to an unconscious challenge. Cognitive Therapy and Research, 30(1), 85-103.

Springer, C., A., Britt, W., T. \& Schlenker R., B. (1998). Codependency: clarifying the construct. Journal of Mental Health Counseling, 20 (2), 141-158.

Tanhan, F. ve Mukba, G. (2014). Spann-Fischer İlişki Bağımlılı̆̆1 Ölçeği'nin Türkçe’ye uyarlama çalışmasına ilişkin psikometrik bir analiz. Pamukkale Üniversitesi Eğitim Fakültesi Dergisi, 36(36), 179-190.

Tolstikova, A. (2010). Codependency in families with alcohol-dependent persons. Medical Health and Science Journal, 2(2), 95-99.

Uğur, E. (2018). Kabul ve Kararlllk Terapisi yönelimli psikoeğitim programmm olumsuz değerlendirilme korkusu üz̧erindeki etkisi (Yayımlanmamış yüksek lisans tezi). Sakarya Üniversitesi Eğitim Bilimleri Enstitüsü, Sakarya.

Ümmet, D. İme, Y. Çağlar, A. ve Akyıl, Y. (2020). Lise öğrencilerinde karar verme: Olumsuz değerlendirilme korkusu ve başarı yönelimlerine göre bir değerlendirme. Humanistic Perspective, 2(2), 68-80.

Wells, M. C., Hill, M. B., Brack, G., Brack, C. J. ve Firestone, E. E. (2006). Codependency's relationship to defining characteristics in college students. Journal of College Student Psychotherapy, 20(4), 71 84.

Yılmaz-Bingöl, T. ve Vural Batık, M. (2018). Psikolojik danışman adaylarının koşulsuz kendini kabul düzeyleri. Insan ve Toplum Bilimleri Arastırmalar Dergisi, 7 (4), 2438-2453. http:/ / www.itobiad. com/issue/39481/444355 